\title{
Pitfalls in TCR gene clonality testing: teaching cases
}

\author{
Patricia J. T. A. Groenen - Anton W. Langerak • \\ Jacques J. M. van Dongen • Johan H. J. M. van Krieken
}

Received: 26 May 2008 / Accepted: 17 July 2008 / Published online: 22 August 2008

(C) The Author(s) 2008. This article is published with open access at Springerlink.com

\begin{abstract}
Clonality testing in T-lymphoproliferations has technically become relatively easy to perform in routine laboratories using standardized multiplex polymerase chain reaction protocols for T-cell receptor (TCR) gene analysis as developed by the BIOMED-2 Concerted Action BMH4CT98-3936. Expertise with clonality diagnostics and knowledge about the biology of TCR gene recombination are essential for correct interpretation of TCR clonality data. Several immunobiological and technical pitfalls that should be taken into account to avoid misinterpretation of data are addressed in this report. Furthermore, we discuss the need to integrate the molecular data with those from immunohistology, and preferably also flow cytometric immunophenotyping, for appropriate interpretation. Such an interactive, multidisciplinary diagnostic model guarantees integration of available data to reach the most reliable diagnosis.
\end{abstract}

Keywords TCR · Clonality · Pitfall · GeneScanning · Lymphoma

Parts of this review have been published in Expert Opinion Medical Diagnostics (2007) 1: 451-461.

P. J. T. A. Groenen $(\bowtie) \cdot$ J. H. J. M. van Krieken

Department of Pathology,

Radboud University Nijmegen Medical Centre,

Geert Grooteplein 24,

6525 GA Nijmegen, The Netherlands

e-mail: P.Groenen@pathol.umcn.nl

A. W. Langerak $\cdot$ J. J. M. van Dongen

Department of Immunology, Erasmus MC,

University Medical Center,

Rotterdam, Netherlands

\section{Introduction}

Cancer cells are the progeny of a single malignantly transformed cell, and consequently, these cells are clonally related. Hence, monoclonality is a key feature of malignant tumor cell populations, which enables discrimination from oligoclonal or polyclonal, reactive processes. Clonality assessment is thus an important tool in the diagnosis of malignant lymphoproliferations, even though clonality does not always imply malignancy because some reactive processes contain large clonal lymphocyte populations. Establishment of the clonal relationship between multiple lesions at distinct locations or over time is another useful application in cancer diagnostics. In lymphoid malignancies, clonality detection is relatively straightforward due to the ample availability of highly polymorphic DNA markers, i.e., the rearrangements in the genes encoding the antigen receptors in B and T lymphocytes, the immunoglobulin (Ig) and T-cell receptor (TCR) genes, respectively [1-4]. During early lymphoid differentiation, genes encoding the Ig and TCR molecules are formed by stepwise rearrangement of variable $(\mathrm{V})$, diversity $(\mathrm{D})$, and joining $(\mathrm{J})$ gene segments. This process is referred to as $\mathrm{V}(\mathrm{D}) \mathrm{J}$ recombination $[3,4]$. During this recombination process, nucleotides are deleted and randomly inserted at the joining sites, resulting in an enormous diversity of unique antigen receptors. As Ig/TCR gene rearrangements occur sequentially in the earliest stages of lymphoid differentiation, they are present in almost all immature and mature lymphoid cells [5-7]. Since lymphomas and leukemias are derived from a single malignantly transformed lymphoid cell, the tumor cells of virtually all lymphoid malignancies contain, in principle, an identical clonal IGH and/or a clonal IGK/IGL rearrangement in B-cell lymphoproliferations and an identical clonal TCRG and/or clonal TCRB gene rearrangement in T-cell 
lymphoproliferations. Heterogeneity in Ig/TCR rearrangements thus identifies the presence of polyclonally activated cells, as opposed to identically rearranged Ig or TCR genes that reflect a monoclonal lymphoid cell population.

In this report, we address several technical and immunobiological pitfalls especially related to TCR clonality and its detection in lymphoid malignancies.

\section{T-cell clonality testing}

In the late 1990s, a European consortium of $\sim 45$ laboratories (BIOMED-2 Concerted Action BMH4-CT98-3936) was initiated with the aim to establish a highly reliable standard in polymerase chain reaction (PCR)-based clonality testing, for B-cell as well as for T-cell malignancies. Figure 1a illustrates a schematic diagram of the human $T C R B$ locus, showing one of the $\mathrm{V} \beta$ gene elements from the $\mathrm{V} \beta$ gene segments, 39-47 are qualified as functional and belong to 23 families. Both $\mathrm{C} \beta$ gene segments $(\mathrm{C} \beta 1$ and $C \beta 2)$ are preceded by a $D \beta$ gene $(D \beta 1$ and $D \beta 2)$ and a $\mathrm{J} \beta$ cluster, which comprises six $(\mathrm{J} \beta 1.1-\mathrm{J} \beta 1.6)$ and seven $(\mathrm{J} \beta 2.1-\mathrm{J} \beta 2.7)$ functional $\mathrm{J} \beta$ segments. A schematic diagram of the human TCRG locus on chromosome band $7 \mathrm{p} 14$ is illustrated in Fig. 2a. The TCRG locus contains only nine $\mathrm{V} \gamma$ gene segments that have been shown to undergo rearrangement. The BIOMED-2-approved set of multiplex $T C R B$ and TCRG PCR tubes, with the position of the primers, are shown in Figs. $1 \mathrm{~b}$ and $2 \mathrm{~b}$, respectively. In the BIOMED-2 approach, the issue of false-negativity was addressed at several levels: (1) design of complete sets of primers to cover all possible $\mathrm{V}-\mathrm{J}$ rearrangements; (2) inclusion of incomplete rearrangements as additional targets (e.g., $D \beta-J \beta$ ); (3) evaluation of multiple targets per sample. This concept of complementarity of targets was only feasible for routine testing by designing multiplex PCR reaction mixtures consisting of multiple primers. The other challenge was to prevent false-positivity, which was achieved by introducing standardized, reliable methods for evaluation of PCR products: heteroduplex analysis [10, 11], and GeneScan fragment analysis [12, 13] (Fig. 3). Following its technical evaluation [14], the multiplex protocol was successfully applied to different well-defined WHO lymphoma entities with unprecedented high frequencies of malignant cases showing clonality [15-20]. The sensitivity of the BIOMED-2 multiplex PCR clonality assays has been evaluated during the primer design and testing phase. The detection of virtually all TCR gene rearrangements has a sensitivity of at least 10\% [14]. Multiplex PCR-based clonality testing and assessment by GeneScan and/or heteroduplex analysis have become a worldwide standard [21-24]. Technically, TCR clonality testing and assessment by GeneScan and/or heteroduplex analysis has become relatively easy to perform. However, knowledge of and experience with TCR rearrangement analysis and inclusion of quality checks in the routine diagnostic setting are essential to avoid misinterpretation of the data.

Following the guideline of the BIOMED-2 group as presented in a flowchart in Fig. 4, both TCRG and TCRB gene rearrangements are analyzed simultaneously in the routine diagnostic setting for T-cell clonality testing because both targets provide complementary information [15]. In addition, usage of both targets in parallel (instead of consecutively) is efficient and fast, since most laboratories run clonality assays not more than once a week. The majority of T-cell neoplasms have clonal TCRG and TCRB rearrangements with clear complementarity of clonality detection [17], which is one of the advantages of the BIOMED-2 clonality testing approach. In fact, the detection of clonal TCRG and clonal TCRB rearrangements in itself is a confirmation of clonality detection. Only rarely, isolated clonal $T C R G$ or $T C R B$ rearrangements are seen. A two-step triage is recommended for testing TCRD rearrangements. Because of its complexity, the single tube TCRD assay should not be routinely used in T-cell clonality diagnostics. $T C R D$ clonality testing is recommended (1) when there is evidence for a TCR $-\gamma \delta$ proliferation through, e.g., flow cytometry, (2) upon detection of an isolated clonal TCRG rearrangement, as this may be considered as indirect evidence for a TCR $-\gamma \delta$ proliferation since $T C R G$ is the second TCR locus after TCRD to undergo gene rearrangements, or (3) when there is a suspicion of an immature T-cell neoplasm, e.g., in case of TdT-positive lymphoblasts.

\section{Quality parameters for clonality testing}

To ascertain reproducible clonality assessment and to avoid misinterpretation of the data, DNA-quality, controlled DNAinput and tissue representativity, are essential quality parameters to be evaluated in the routine diagnostic setting [25].

Testing the quality of the extracted DNA from the pathological specimen is an important parameter, particularly when using formalin-fixed and paraffin-embedded (FFPE) tissues. The quality of the extracted DNA from FFPE tissues might be poor, such that the TCR gene targets are not efficiently amplified. DNA quality should therefore always be checked in a control PCR analysis in which a range of differently sized PCR products from nonpolymorphic genes are amplified [14]. The BIOMED-2 primers are designed and validated for DNA-clonality analysis from fresh or fresh frozen tissues. Although the primers have not been universally accepted for FFPE tissues, many laboratories use the BIOMED-2 primers for FFPE samples as well. Indeed, when extracted DNA from FFPE samples 


\section{a}

TCRB gene complex (\#7q34)

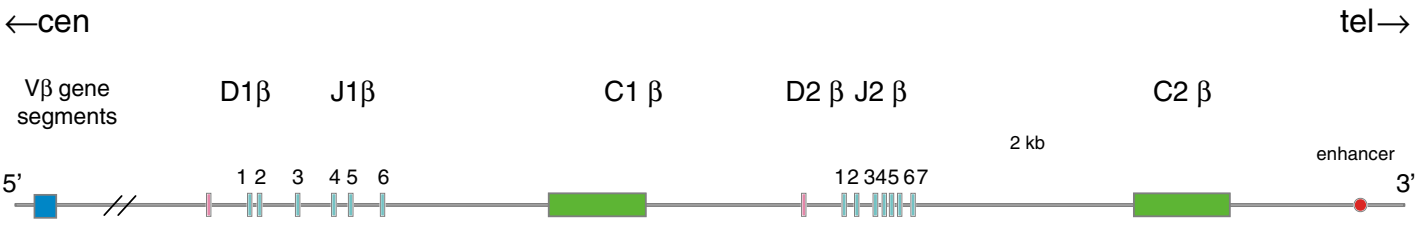

Adapted from IMGT database, M.P. Lefranc, Leukemia 2003; 17: 260-266

b

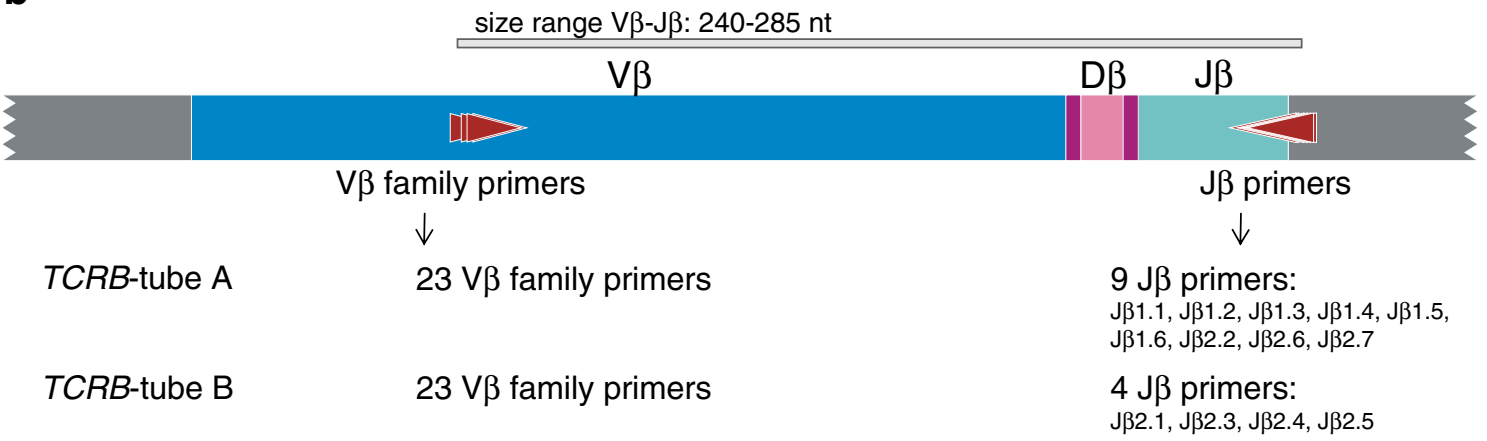

size range $D \beta 1-J \beta: 285-325 \mathrm{nt}$

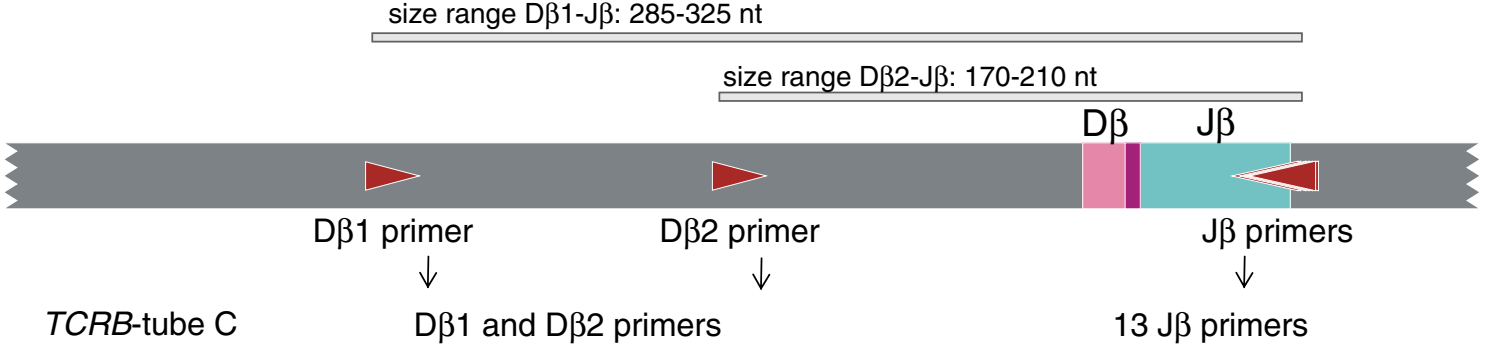

Fig. 1 PCR analysis of TCRB gene rearrangements. a Schematic diagram of the human TCRB locus on chromosome band 7q34. The figure is adapted from the international ImMunoGeneTics database [8, 9]. Only one of the rearrangeable nonpolymorphic functional $\mathrm{V} \beta$ gene segments is depicted (in blue). Both $\mathrm{C} \beta$ gene segments $(\mathrm{C} \beta 1$ and $\mathrm{C} \beta 2$, depicted in green) are preceded by a $\mathrm{D} \beta$ gene $(\mathrm{D} \beta 1$ and $\mathrm{D} \beta 2$, depicted in pink) and a $\mathrm{J} \beta$ cluster, depicted in light blue. b Schematic

shows amplification up to $300 \mathrm{bp}$ of the control gene PCR, TCR clonality testing using the BIOMED-2 primers for $T C R B$ and TCRG is very well feasible. These FFPE samples have a high detection rate of clonality comparable to that from fresh frozen samples [Section 10 in 14] (personal observation). However, when the DNA is fragmented and shows amplification of 200 or even only $100 \mathrm{bp}$ of the BIOMED-2 control gene PCR, the TCRBgene targets (due to the amplicon size of $240-285 \mathrm{bp}$ in tubes $\mathrm{A}$ and $\mathrm{B}$, and $170-210$ and $285-325 \mathrm{bp}$ in tube C) may not efficiently be amplified and therefore potentially yielding false-negative results [Section 10 in 14]. The $T C R B$ GeneScan profiles from fragmented DNA samples diagram of $\mathrm{V} \beta-\mathrm{J} \beta$ and $\mathrm{D} \beta-\mathrm{J} \beta$ rearrangements. The $23 \mathrm{~V} \beta$ primers, $13 \mathrm{~J} \beta$ primers, and two $\mathrm{D} \beta$ primers are combined in three tubes: tube A with $23 \mathrm{~V} \beta$ primers and nine $\mathrm{J} \beta$ primers, tube $B$ with $23 \mathrm{~V} \beta$ primers and four $\mathrm{J} \beta$ primers, and tube $C$ with two $D \beta$ primers and 13 $\mathrm{J} \beta$ primers. The $\mathrm{V} \beta$ primers cover approximately $90 \%$ of all $\mathrm{V} \beta$ gene segments. Adapted from BIOMED-2 report [14]

may thus be difficult to interpret and may give ambiguous results. Therefore, we do not recommend testing TCRB gene rearrangement in the case of fragmented DNA samples. For the cases showing fragmented DNA, the $T C R G$-gene target is more useful and reliable as the multiplex PCRs for TCRG gene rearrangements yield lower amplicon sizes between 80 and $255 \mathrm{bp}$. The detection rate of T-cell clonality using the TCRG gene as target on DNA from fresh frozen cases still is $89 \%$ [17].

Controlled DNA input is also an important quality parameter because the lack of both monoclonal and polyclonal signals, or nonreproducible patterns in a given sample might be explained by too low or too high amount of 


\section{a}

\section{TCRG gene complex (\#7p14)}

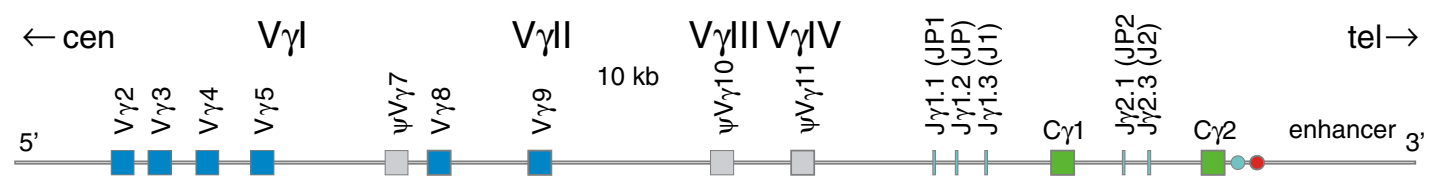

silencers

b

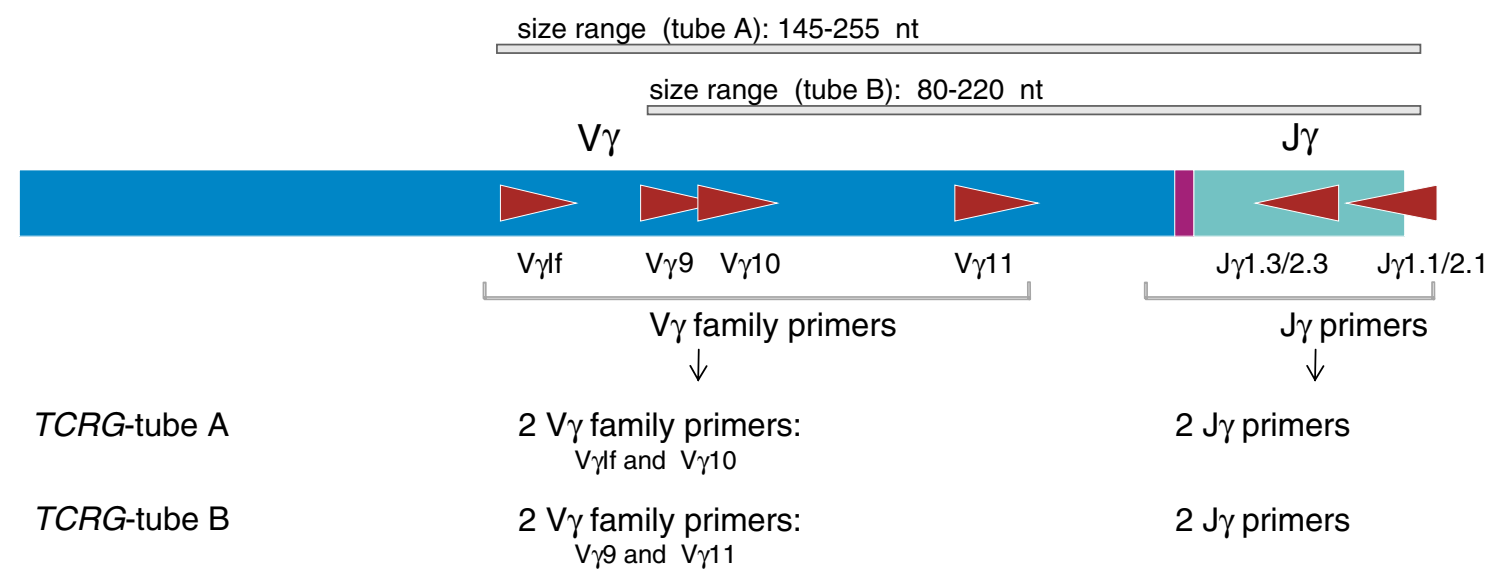

Fig. 2 PCR analysis of $T C R G$ gene rearrangements. a Schematic diagram of the human TCRG locus on chromosome band $7 \mathrm{p} 14$. Only the rearrangeable $\mathrm{V} \gamma$ gene segments are depicted in blue (functional

target DNA in the sample, the former due to a low number of T-lymphocytes in the tissue, the latter due to PCRinhibiting factors in the extracted DNA. The latter might particularly occur in FFPE-derived DNA samples that are obtained by DNA-extraction methods without further purification. The input of DNA per PCR is important to be evaluated in order to be sure that sufficient DNA originating from target T-lymphoid cells is analyzed and thus to confirm clonality results. In addition, it is important to exclude pseudo-clonality, which may occur in the case of low input of target T-lymphoid cells. In general, 100 ng DNA is used per PCR (50 ul) for DNA samples obtained from snapfrozen tissues. For FFPE-samples, we recommend a standard DNA-extraction procedure using an affinity-purification step to get rid of small (degraded) DNA strands. Because of the probability of PCR-inhibiting factors in the sample, two concentrations, 50 and $200 \mathrm{ng}$ DNA per PCR (50 ul), are used. Adjustment of the DNA input may be necessary when there is a low percentage $(5-10 \%)$ of $\mathrm{T}$ cells present in the tissue sample. The DNA input in these cases is maximally increased to $400 \mathrm{ng} / \mathrm{PCR}$. To quantitate DNA, affinity purification of DNA followed by spectrophotometrical DNA-concentration measurement is recommended.

A third important parameter is tissue representativity. The number of $\mathrm{T}$ lymphocytes and the number of suspect
$\mathrm{V} \gamma$ ) or in gray (nonfunctional $\mathrm{V} \gamma$ ). $\mathbf{b}$ Schematic diagram of $T C R G \mathrm{~V} \gamma$ $\mathrm{J} \gamma$ rearrangement with four $\mathrm{V} \gamma$ primers and two $\mathrm{J} \gamma$ primers, which are divided over two tubes. Adapted from BIOMED-2 report [14]

malignant $\mathrm{T}$ cells, should be checked by histological examination of the same tissue material that was used for DNA extraction (HE staining of the slides directly prior to and following the DNA extraction slides) by an experienced hematopathologist and/or supported by flow cytometry data whenever available.

Furthermore, we advise for any clonality testing to include not only monoclonal cell lines [14, 26], but also polyclonal samples such as peripheral blood mononuclear cells showing the typical polyclonal pattern of TCR gene products with a heterogeneous junctional size distribution. Such polyclonal control samples act as control for primer quality as well. In addition, samples without rearranged Ig/ TCR genes (e.g., the HeLa epithelial cell line) can be informative to identify nonspecific bands/peaks that are sometimes found in multiplex assays [14]. These three types of control samples facilitate the interpretation of patterns in the clinical samples.

\section{Interpretation of T-cell clonality data: teaching cases}

For interpretation of clonality data, especially in difficult cases, which are the ones that are also difficult for pathologists, knowledge of and experience with analysis of 
A

$\mathrm{V} \beta$

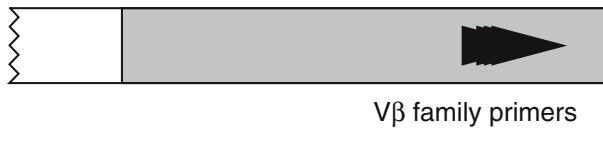

B

\section{Heteroduplex analysis}

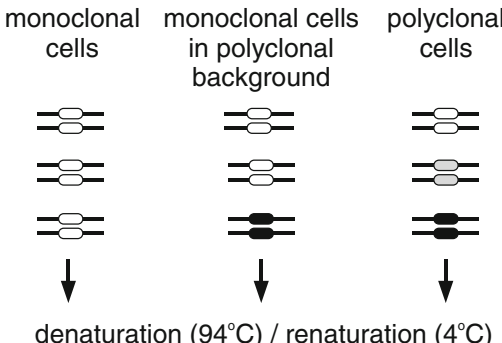

$=$

$=\varnothing$

=ㄷ
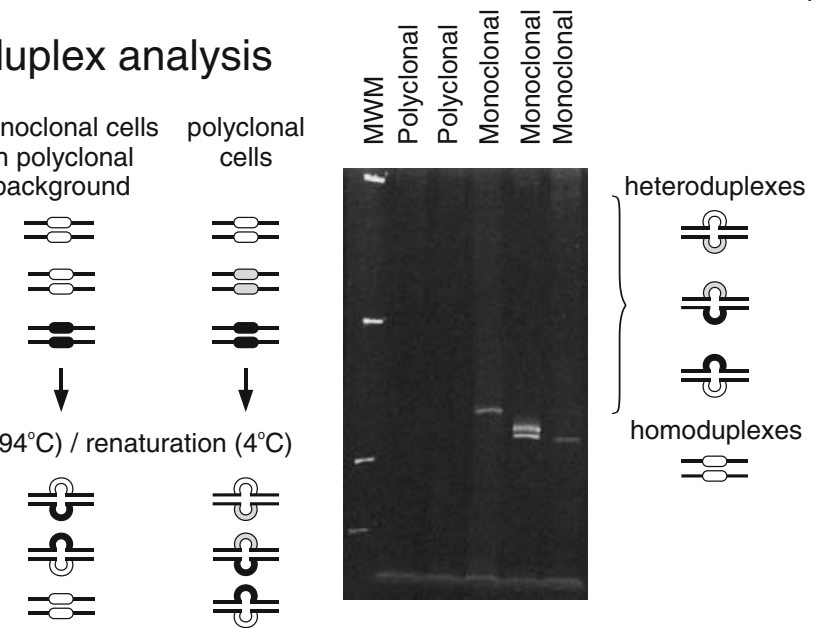

homoduplexes

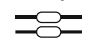

$\mathrm{J} \beta$

$\mathrm{D} \beta$

T1
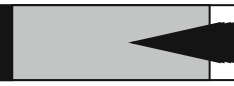

$\mathrm{J} \beta$ primers

Fig. 3 Schematic diagram of heteroduplex analysis and GeneScan fragment analysis of PCR products from TCR gene rearrangements. a Rearranged TCR genes (here TCRB rearrangements are shown as example) show heterogeneous junctional regions (also known as junctional motifs) that differ in size and nucleotide composition. V, D, and $\mathrm{J}$ germline nucleotides are shown in large capital and randomly inserted nucleotides in small capital. Junctional heterogeneity can be exploited to discriminate between polyclonal and monoclonal PCR products based on differences in size and composition (heteroduplex analysis) or size only (GeneScan fragment analysis). b In heteroduplex analysis, PCR products are denatured $\left(5 \mathrm{~min}, 94^{\circ} \mathrm{C}\right)$ and reannealed

TCR gene rearrangements are required to avoid misinterpretation of the data. Molecular biologists, pathologists, and clinicians should be aware of several technical and immunobiologic pitfalls that should be considered when interpreting TCR clonality findings (Table 1, adapted from Langerak et al., [25]). Specific aspects of the data analysis will be discussed by demonstration of two illustrative cases.

Case 1 concerns a skin lesion of a patient suspected for cutaneous T-cell lymphoma. Two skin biopsies, from the palm of the hand and from the arm were used for diagnosis. The histology of the lesion, showing a polymorphous infiltrate consisting of CD2-positive lymphocytes, is shown in Fig. 5. For molecular analysis, snap-frozen tissue biopsies from two sites were used, containing $80 \% \mathrm{~T}$ cells of which at least $10 \%$ were suspected to be malignant $\mathrm{T}$ cells. The quality of the extracted DNA from both biopsies was fine, showing an amplification up to $400 \mathrm{bp}$ of the BIOMED-2 control gene PCR (using the 100-, 200-, 300-, 400- amplicons) [16]. The clonality profile of this patient is presented in Fig. 6. For this patient, we showed that both

skin biopsies from the patient showed identically sized TCR gene rearrangements, which supports the clonal nature of the skin lesions.

Case 2 concerns a patient with an atypical T-cell infiltrate in the cerebellum, shown in Fig. 7. Clonality assessment was performed to assess whether infiltrated $\mathrm{T}$ cells were clonal, which may fit to a malignant T-cell process. FFPE tissue, containing 30\% of T cells, most of which were suspected to be malignant, was available for clonality testing. Amplification of the extracted DNA was good (400 bp products could be amplified). Due to the genomic organization of the TCRG locus and the primer compositions of the BIOMED-2 TCRG multiplex tubes, the multiple (at least three) "clonal" TCR $G$ peaks observed as shown in Fig. 8 are consistent with the presence of at least two dominant T-cell clones (one clone with TCRG biallelic rearrangements and one with a single $T C R G$ rearrangement) in a polyclonal background of $\mathrm{T}$ cells. The molecular data support the morphological findings of a suspect lesion in the cerebellum, which now is classified as a peripheral Tcell lymphoma. 


\section{BIOMED-2 clonality strategy}

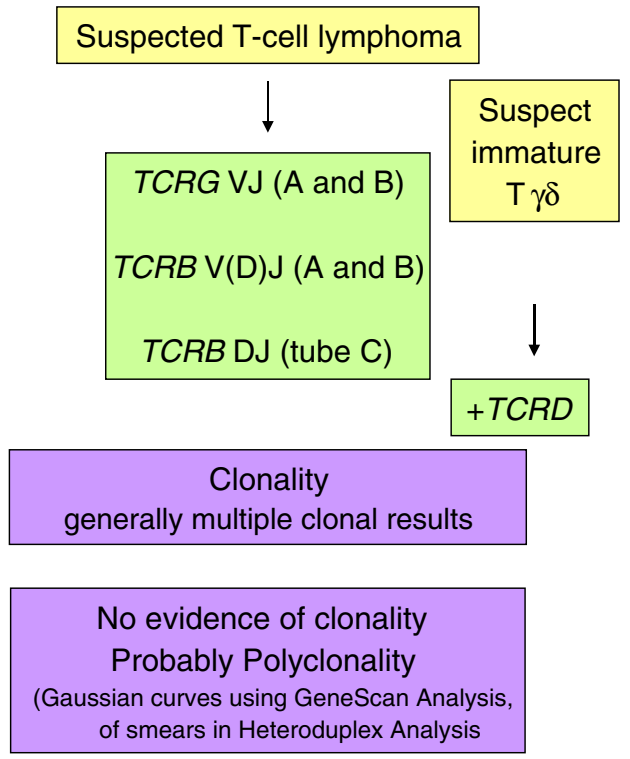

Fig. 4 Flow chart for clonality testing for suspected T-cell proliferations. Both TCRG and TCRB gene rearrangements are analyzed simultaneously because of complementarity of the targets and, as such, increase the clonality detection rate. For tissues showing fragmented DNA, testing the $T C R G$-gene target is most useful and reliable because of the lowerlength amplicon sizes. Assessment of TCRB is not recommended in the case of severe fragmentation of DNA samples

Generation and technical interpretation of GeneScan clonality profiles

In the clonality profiles of the two cases (Figs. 6 and 8), it should be noted that the $Y$-axes are adjusted so that all histograms appear similar, with the strongest peak near the top of the histogram. It is clear that some gene rearrangement amplifications are less abundant than others. The BIOMED-2 group is aware that in the multiplex PCR tubes primers have different PCR efficiencies. A good example is the TCRB-tube $\mathrm{B}$, which is less efficient compared to the other TCRB tubes and therefore will always give weaker PCR products. Because of the different PCR efficiencies, every PCR tube should be interpreted individually (using adjusted $Y$-axis), making use of the normal Gaussian distribution seen in polyclonal pattern of the specific target.

A dominant clonal product in a polyclonal background of cells is seen in some of the targets, like the TCRG-tube $\mathrm{A}$, which assesses the $\mathrm{V} \gamma 1 \mathrm{f}$ and $\mathrm{V} \gamma 10$ rearrangements (Fig. 6a), and the TCRB-tube $\mathrm{C}$, which assesses the incomplete DJ joinings of the TCRB locus (Fig. 6b). Precise measuring peak intensities or area under the peak is not the way to interpret clonality results. The BIOMED-2 group argues against strictly quantitative approaches that compare the size (or area under the peak) of the seemingly dominant peak with neighboring peaks in PCR reactions with a significant polyclonal background, simply because the multiplex PCRs are not strictly quantitative and because such quantitative approaches are influenced by the size of the junctional regions of the clonal peaks. Short and long junctional regions more likely lead to a "clonal" diagnosis than intermediately sized junctional regions. Therefore, the different BIOMED-2 multiplex PCRs should not be interpreted using an exact algorithm and quantitative rules. For interpretation of the clonality profiles, it is, of course, evident that the clonal peak should dominate clearly above the polyclonal background (as illustrated in Fig. 6a for $T C R G$-tube A). Instead of using strict quantitative rules, however, we strongly recommend the use of an "inverse" approach in which immunohistological information and preferably also flow cytometric immunophenotyping information about the size of the entire lymphocyte population and the suspect malignant lymphocyte population are used to interpret the profile and the distribution of the peaks. The dominant peak in TCRG-tube A (Fig. 6a) may fit to tumor tissue containing $80 \% \mathrm{~T}$ cells of which at least $10 \%$ were suspected to be malignant. The dominant clonal peak in tube A would not fit, for example, to a tumor tissue containing $80 \% \mathrm{~T}$ cells, all of which were suspected to be malignant. Note that both the multiplex PCRs as well as the estimation of the total number of $\mathrm{T}$ lymphocytes and the number of suspect malignant cells are not strictly quantitative. However, it is clear that the clonality profile and the percentage of suspect malignant cells are related, and therefore, it is important to use the available immunehistological information on the percentage of $\mathrm{T}$ lymphocytes and the percentage of suspect malignant $T$ cells for the final evaluation of the molecular result. We are aware that some molecular laboratories apply a strictly quantitative approach for clonality assessment, without consulting the pathologist for the histopathological information. We argue against such practical approach because a strictly quantitative approach can easily miss clonal processes or, more dangerously, can erroneously assess "clonality". It is better to use the(immuno)histopathological information, the knowledge of the PCR target and to apply the multiple target TCR approach (TCRB and TCRG) and evaluate the entire profile of gene rearrangements, in order to reach a correct interpretation of the clonality results.

Repeating the PCR analysis might provide extra information. In diagnostic studies in the case of ambiguous results or in the case of an isolated target, repeated analysis using the same sample, a second independent DNA extraction from the same sample and/or a related sample is necessary to evaluate consistency of results. Note that ambiguous results (results that are not reproducible or difficult to interpret) are mostly derived from DNA samples from FFPE samples. The TCRB-C tube that corresponds to 
Table 1 Pitfalls in TCR clonality testing ${ }^{\mathrm{a}}$

\begin{tabular}{|c|c|c|}
\hline Pitfall & Phenomenon & Solution/action \\
\hline Bands/peaks just outside size range & $\begin{array}{l}\text { Junctional regions/junctions } \\
\text { outside } 5-95 \% \text { size range interval }\end{array}$ & $\begin{array}{l}\text { Accept as true rearrangement product; in case of doubt, sequence } \\
\text { for confirmation }\end{array}$ \\
\hline Undersized bands/peaks & $\begin{array}{l}\text { Internal deletion in, e.g., } \mathrm{V} \\
\text { segment }\end{array}$ & Potential rearrangement product; confirm by sequencing \\
\hline Oversized bands/peaks & $\begin{array}{l}\text { Extended amplification from } \\
\text { downstream J }\end{array}$ & Potential rearrangement product; confirm by sequencing \\
\hline Multiple clonal signals & $\begin{array}{l}\text { Bi-allelic rearrangements; multiple } \\
\text { rearrangements per allele or } \\
\text { biclonality }\end{array}$ & $\begin{array}{l}\text { Consider the number of potential rearrangements per allele and } \\
\text { per locus and judge whether this fits with clonality or biclonality }\end{array}$ \\
\hline $\begin{array}{l}\text { Lack of clonal signal and lack of } \\
\text { polyclonal Gaussian curve }\end{array}$ & $\begin{array}{l}\text { Few T cells in sample } \\
\text { Low DNA input/PCR } \\
\text { Poor DNA quality }\end{array}$ & $\begin{array}{l}\text { Check T cell presence by histology or flow cytometry } \\
\text { Check DNA concentration } \\
\text { Check DNA quality in control PCR }\end{array}$ \\
\hline $\begin{array}{l}\text { Selective amplification and } \\
\text { pseudoclonality, due to low level of } \\
\text { specific template }\end{array}$ & Few $T$ cells in sample & $\begin{array}{l}\text { Repeat PCR in multiplicates (same tissue, second independent } \\
\text { DNA isolation, and/or related tissue) } \rightarrow \text { compare patterns for } \\
\text { consistency }\end{array}$ \\
\hline $\begin{array}{l}\text { Oligoclonal T-cell repertoire in PB of } \\
\text { especially elderly individuals }\end{array}$ & $\begin{array}{l}\text { Incomplete immune system, due } \\
\text { to, e.g., immunosenescence }\end{array}$ & $\begin{array}{l}\text { Repeat PCR in multiplicates (same tissue, second independent } \\
\text { DNA isolation, and/or related tissue) } \rightarrow \text { compare patterns for } \\
\text { consistency and compare with primary process }\end{array}$ \\
\hline $\begin{array}{l}\text { Oligo-/monoclonality in } \\
\text { histologically reactive lesion }\end{array}$ & $\begin{array}{l}\text { Exaggerated immune response } \\
\text { with dominant specificity }\end{array}$ & $\begin{array}{l}\text { Repeat PCR in multiplicates (same tissue, second independent } \\
\text { DNA isolation, and/or related tissue) } \rightarrow \text { compare patterns for } \\
\text { consistency } \\
\text { (Re)evaluate histopathology } \rightarrow \text { note that large germinal centers in } \\
\text { the tissue may contain dominant T-cell clone(s) }\end{array}$ \\
\hline
\end{tabular}

${ }^{\mathrm{a}}$ Adapted from Langerak et al. [25]

the $T C R B$-DJ incomplete rearrangements may be such an example. For this target, a polyclonal sample should show two Gaussian curves, with a first set of peaks around 180 bp representing the $\mathrm{D} \beta 2$ rearrangements and a second set of peaks around $300 \mathrm{bp}$ representing the $\mathrm{D} \beta 1$ rearrangements. The $\mathrm{D} \beta 1$ and $\mathrm{D} \beta 2$ gene rearrangements can be well evaluated in cases that show good amplification. However, in other cases, the quality of DNA samples may be

Fig. 5 Histology of the skin biopsy, showing underneath the epidermis a polymorphous infiltrate consisting of lymphocytes, eosinophilic granulocytes admixed with large atypical cells. A detail of these cells shows the big nuclei and nucleoli and the irregular nuclear contour. The cells are positive in the CD2 staining but they lack CD3
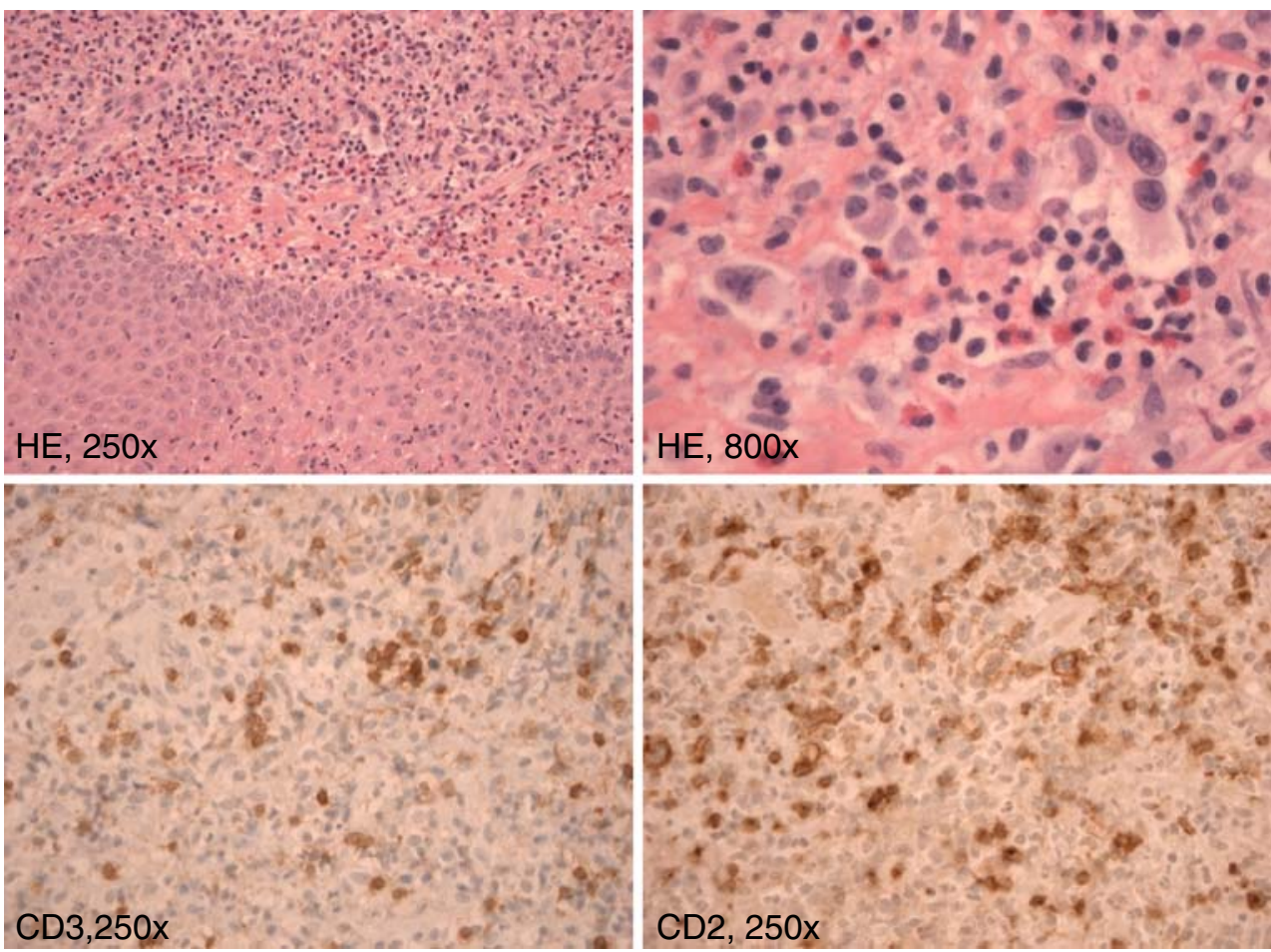
a

TCRG- $A$

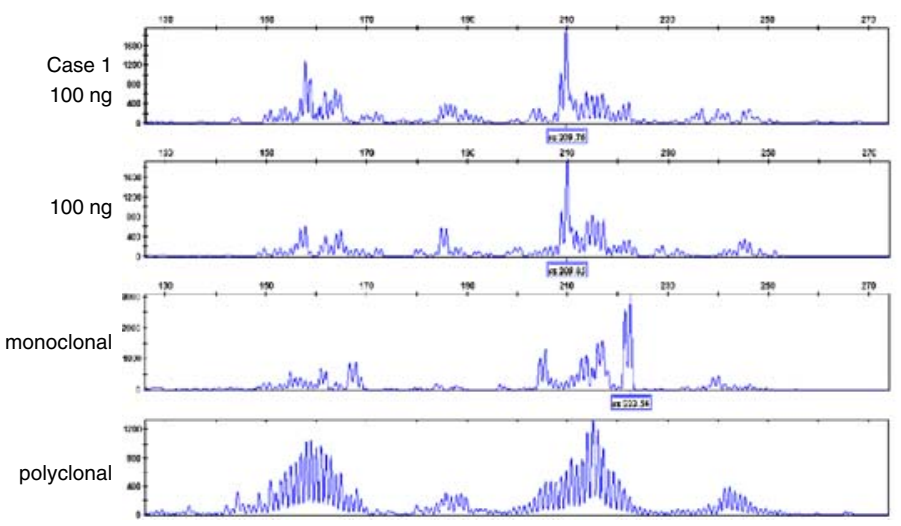

TCRG- B
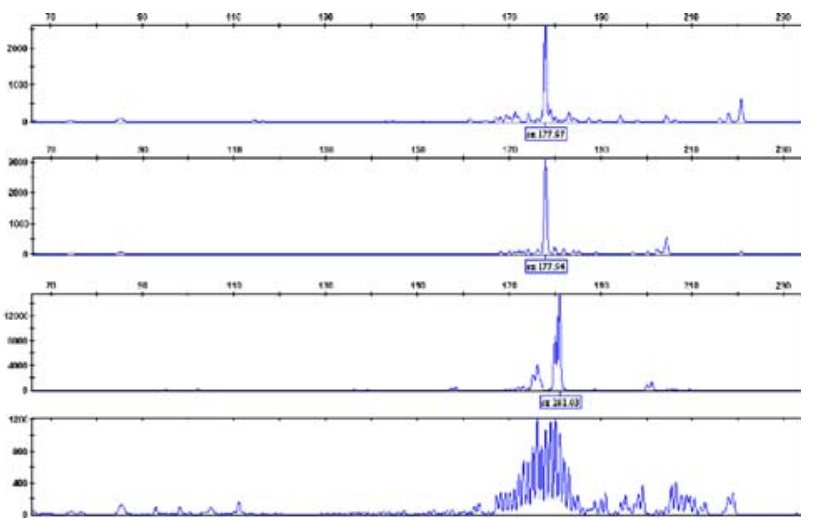

b

TCRB- $A$

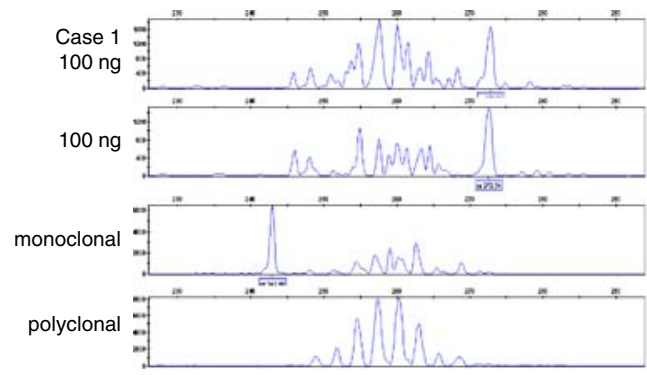

Fig. 6 TCR clonality profiles from a diagnostic tissue suspicious for cutaneous T-cell lymphoma. GeneScan results of the $\mathrm{V} \gamma-\mathrm{J} \gamma$ TCRG gene rearrangements using the BIOMED-2 TCRG-tubes A and $\mathrm{B}(\mathbf{a})$; and of the $\mathrm{V} \beta-\mathrm{J} \beta$ and $\mathrm{D} \beta-\mathrm{J} \beta$ TCRB gene rearrangements using the BIOMED-2 TCRB-tubes A, B and C, respectively (b). Shown are the results of the extracted DNA from the patients' tissue (case 1) in duplicate (100 ng input/PCR), a monoclonal control sample (from a Tcell lymphoma tissue), and a polyclonal control (from a reactive lesion). TCR clonality analysis of case 1 showed two clonally

insufficient to amplify the larger $\mathrm{D} \beta 1$ products, not allowing a proper judgment of this PCR because a potentially clonal target in these cases may remain undetected. Also, upon diagnostic requests of cutaneous NHL or skin biopsies with low numbers of $\mathrm{T}$ cells, we strongly recommend analyzing a second, independent tissue block from a different site whenever available or at least ask for follow-up of the patient. Repeated analysis of a related but independent sample is essential to check for consistency of the pattern.

With respect to expected size ranges of PCR products that are mentioned in protocols for a given TCR target, it is important to realize that those represent the 5-95 percentiles of the natural heterogeneity of the junctional region $[14,27]$. Hence, bands or peaks just outside this size range can be interpreted as true rearrangement products, even without formal proof via sequencing. When the products are considerably smaller (undersized) or larger (oversized),
TCRB- $B$

TCRB- $C$

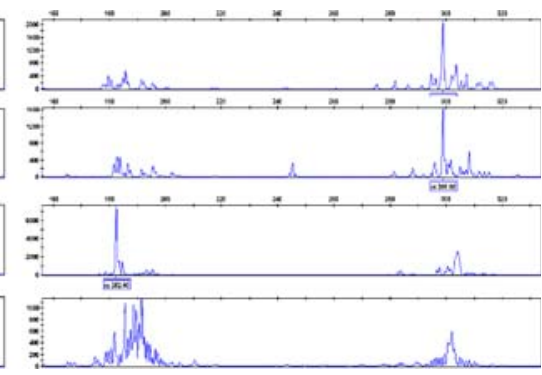

rearranged $T C R G$ genes, which fits to biallelic $T C R G$ clonal rearrangements (a). Also a clonal TCRB-DJ incomplete rearrangement was detected (b: TCRB tube C). The rearrangement pattern of the $T C R B$-tube A shows a peak pattern, which is interpreted as polyclonal (low signal) (b). The peak at $273 \mathrm{bp}$ is a so-called false peak as described before [16, Table 25], since this peak is particularly seen in samples with low numbers of T cells or in samples in which the clonal $T C R B$ product is seen in one of the other TCRB tubes, which fits with the current case they still can represent true rearrangements, but then sequencing analysis is warranted for confirmation.

Not all lymphoma cases need to be evaluated for clonality assessment because most cases can be diagnosed based on morphology and immunohistology supplemented by translocation detection or cytogenetics. Molecular clonality assessment is generally performed on $10-15 \%$ of the lymphoma cases, the percentage being dependent on the experience of the hematopathologist. In our setting of clonality diagnostics, approximately $5 \%$ of evaluated cases give problems in the interpretation of molecular TCR-clonality results. The difficulties in these cases are severe degradation of DNA and, consequently, greatly decreased PCR efficiencies resulting in ambiguous results or the interpretation of a small clonal peak in a high polyclonal background, seen in an isolated target. For the latter, our strategy is to assess a second, independent tissue block from a different site whenever available or ask for follow-up of the patient. 
Fig. 7 Histology of the brain biopsy, showing a mainly lymphoid infiltrate with a mixture of lymphocytes, including some larger atypical ones that are CD3 positive
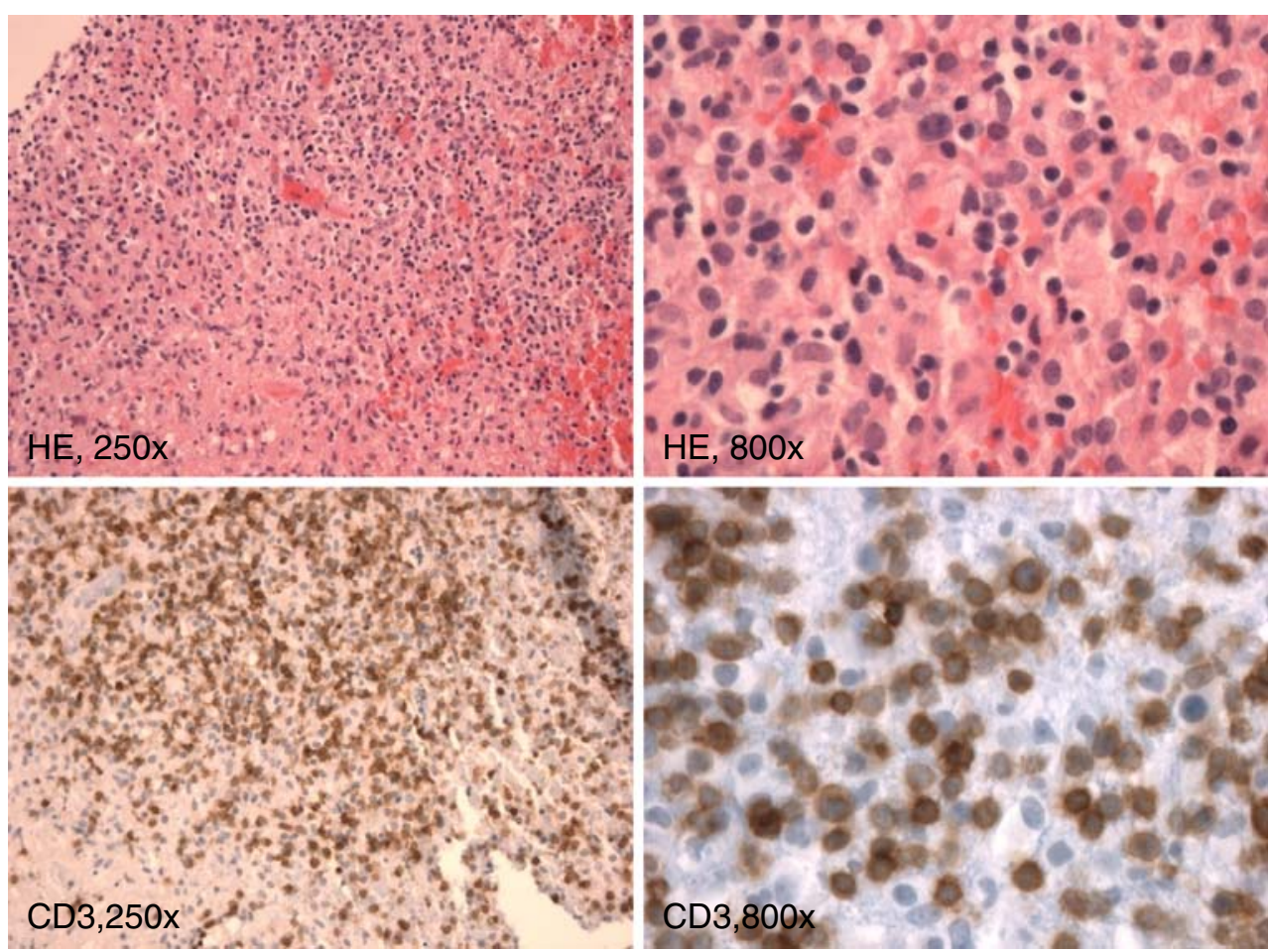

Heteroduplex analysis or GeneScanning

Heteroduplex analysis is another tool to analyze the PCR products for discrimination between monoclonal lymphoid cells with identical junctional regions and polyclonal lymphoid cells with highly diverse junctional regions. Heteroduplex analysis uses double-stranded PCR products and takes advantage of the length and composition of the junctional regions, whereas in GeneScanning, singlestranded PCR products are separated in a high-resolution gel or polymer according to their length only (Fig. 3). The heteroduplex technique is rapid, simple, and cheap and has a detection limit of $5-10 \%[10,11]$. The detection limit is influenced by the frequency of polyclonal lymphocytes because the formation of many heteroduplexes will also consume a part of the monoclonal PCR products [11]. Since heteroduplex analysis separates PCR products on the basis of junctional diversity in addition to PCR product size, it is particularly useful in the analysis of loci with restricted junctional diversity like that for the TCRG-gene rearrangements. For the TCRB-gene rearrangements, heteroduplex analysis is particularly useful for the TCRB PCR tubes A and $\mathrm{C}$ (the TCRB VDJ and the incomplete DJ rearrangements, respectively) and slightly less for tube B (the other set of TCRB VDJ gene rearrangements) because this multiplex PCR is less efficient compared to the other $T C R B$ tubes. For this reason, the TCRB PCR tube B will always give weaker PCR products, which can less easily be detected using heteroduplex analysis because this approach is less sensitive compared to GeneScanning. GeneScanning is rapid and relatively simple, but needs expensive equipment. GeneScanning is generally more sensitive than heteroduplex analysis and can reach sensitivities of $1-5 \%$ of clonal lymphoid cells. We prefer the use of GeneScanning because of its sensitivity. In addition, the precise determination of the size of the PCR product can potentially be used for nonquantitative monitoring of the clonal proliferation during follow-up of the patient.

\section{Multiple clonal rearrangements}

Knowledge of the TCR loci, immunobiology, and the pitfalls of the multiplex approach are needed for proper interpretation of multiple clonal PCR products from one of the TCR gene targets.

In the TCRB locus, the $\mathrm{J}$ gene segments of the two $\mathrm{J} \beta$ clusters have relatively small intergenic distances (a few hundred basepairs). Consequently, multiple clonal products may arise by amplification from a downstream $\mathrm{J}$ gene segment, resulting in "oversized" peaks/bands. Sometimes, this leads to two differently sized PCR products within the same reaction mixture because of efficient primer annealing to both the rearranged and the neighboring downstream $\mathrm{J} \beta$ segment (Fig. 9) [27]. Due to the composition of the BIOMED-2 TCRB multiplex tubes with two $\mathrm{V}-\mathrm{J}$ reaction mixtures harboring mutually exclusive sets of $\mathrm{J} \beta$ primers, the situation can look even more complex. In particular cases, the same $\mathrm{V} \beta-\mathrm{J} \beta$ rearrangement can be identified with both mixtures, with the second mixture giving rise to an "oversized" product because the neighboring down- 
a

TCRG- $A$

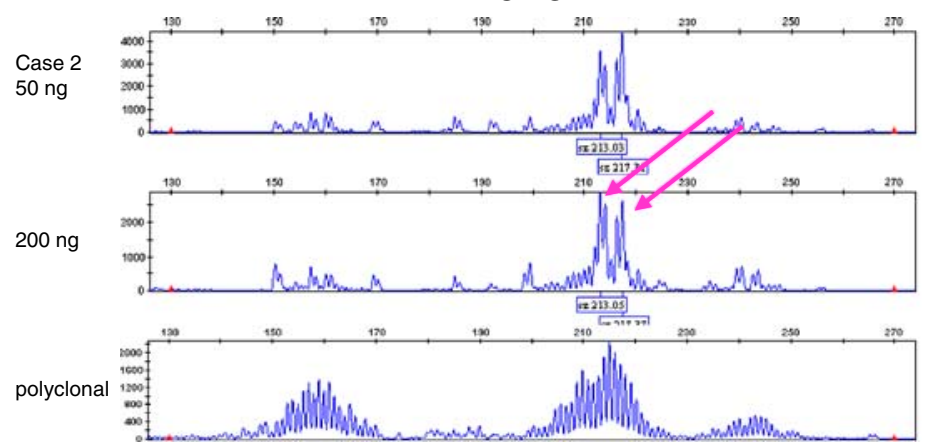

TCRG- $B$

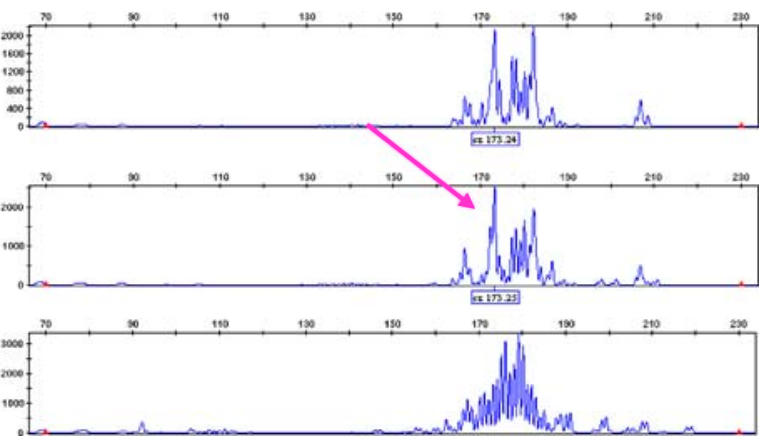

b

TCRB- $A$

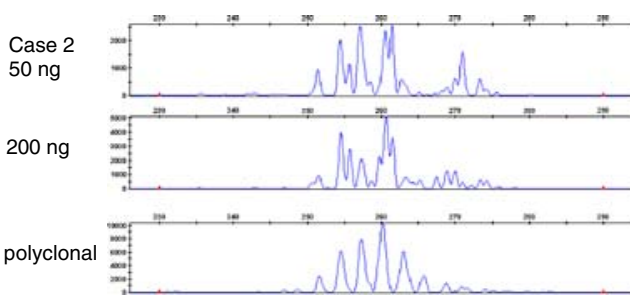

TCRG- $A$

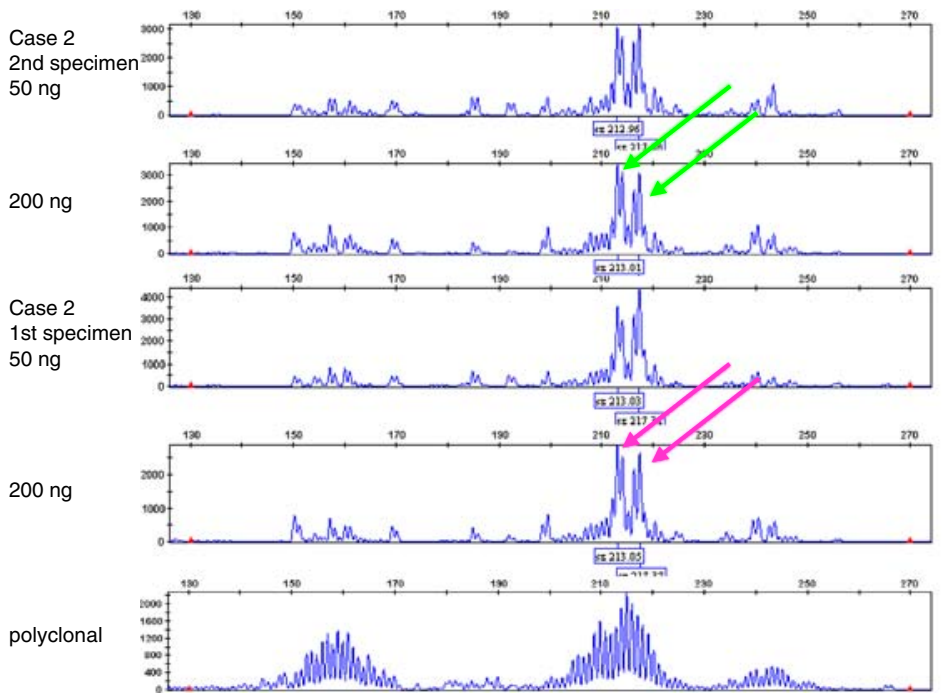

TCRB- $B$

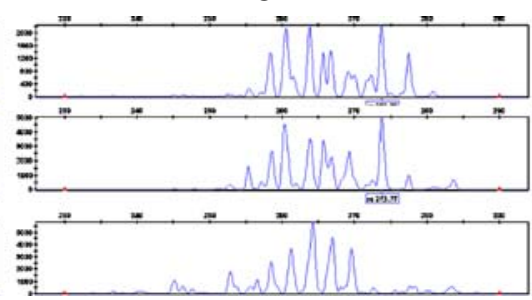

TCRB- $C$

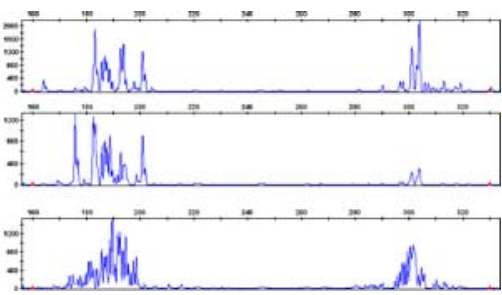

TCRG- $B$
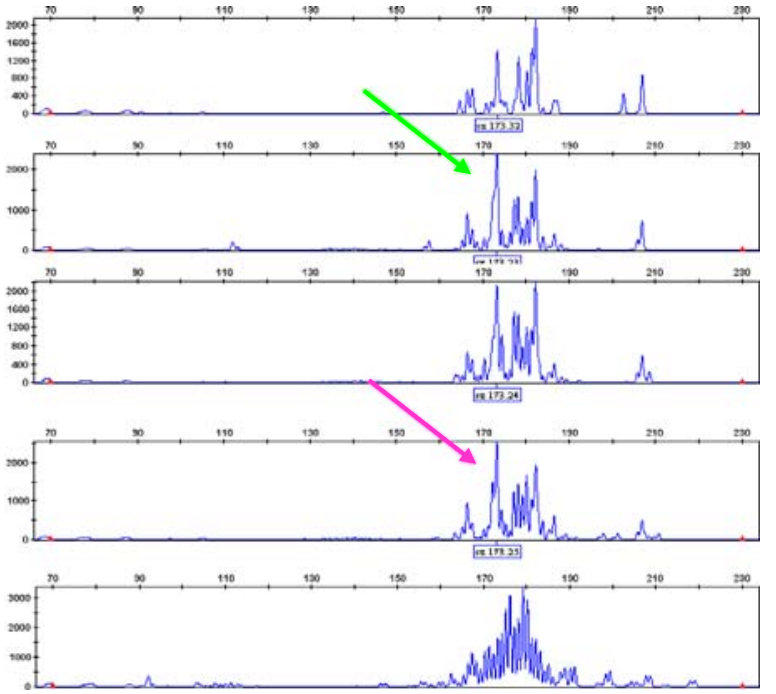

Fig. 8 TCR clonality profiles from a diagnostic tissue from the cerebellum which is suspicious of a malignant lesion. GeneScan results of the $\mathrm{V} \gamma-\mathrm{J} \gamma$ TCR $G$ gene rearrangements using the BIOMED$2 T C R G$-tubes $\mathrm{A}$ and $\mathrm{B}$ (a and $\mathbf{c}$ ) and of the $\mathrm{V} \beta-\mathrm{J} \beta$ and $\mathrm{D} \beta-\mathrm{J} \beta T C R B$ gene rearrangements using the BIOMED-2 TCRB-tubes $\mathrm{A}, \mathrm{B}$, and $\mathrm{C}$, respectively (b). Shown are the results of the extracted DNA from the patients' tissue (case 2) in duplicate (50 and $200 \mathrm{ng}$ input/PCR), with the arrows indicating the suspect clonal peaks, a monoclonal control sample (from a T-cell lymphoma tissue) and a polyclonal control (from a reactive lesion). Clonality analysis of the TCRG gene rearrangements of case 2 demonstrated suspect clonal peaks in a polyclonal background of T-cells (a). The interpretation of these

ambiguous clonality profiles was initially difficult. Polyclonal TCRB rearrangements were observed in this case (b). The clonality profiles of 50 and $200 \mathrm{ng}$ input of tube $\mathrm{C}$ are slightly different, but in both concentrations, many PCR products are amplified, without dominance of a particular peak, and so these are considered polyclonal. Note that the higher amplicon products of the $\mathrm{D} \beta 1$ rearrangements amplify most efficiently in the tube with $50 \mathrm{ng}$ DNA input. Also, TCRD rearrangements were polyclonal (not shown). From the cerebellum lesion, a second independent and representative tissue block was available, which showed the presence of a reproducible profile of the TCRG rearrangement profile (c). The profiles from both biopsies provide evidence for the presence of multiple dominant T-cell clones 
Fig. 9 Two differently sized PCR products arising from the same TCRB rearrangement. Schematic representation of the $T C R B$ locus. Shown is an anaplastic large cell lymphoma (ALCL) sample (case 2005-082) in which the $\mathrm{V} \beta 22-\mathrm{J} \beta 2.3$ rearrangement is amplified with the $\mathrm{J} \beta 2.3$ primer from BIOMED-2 TCRB mixture $\mathrm{B}$, while the same rearrangement is also amplified as an "oversized" product with the $\mathrm{J} \beta 2.4$ primer in the same mixture B. Adapted from Langerak et al. [25]

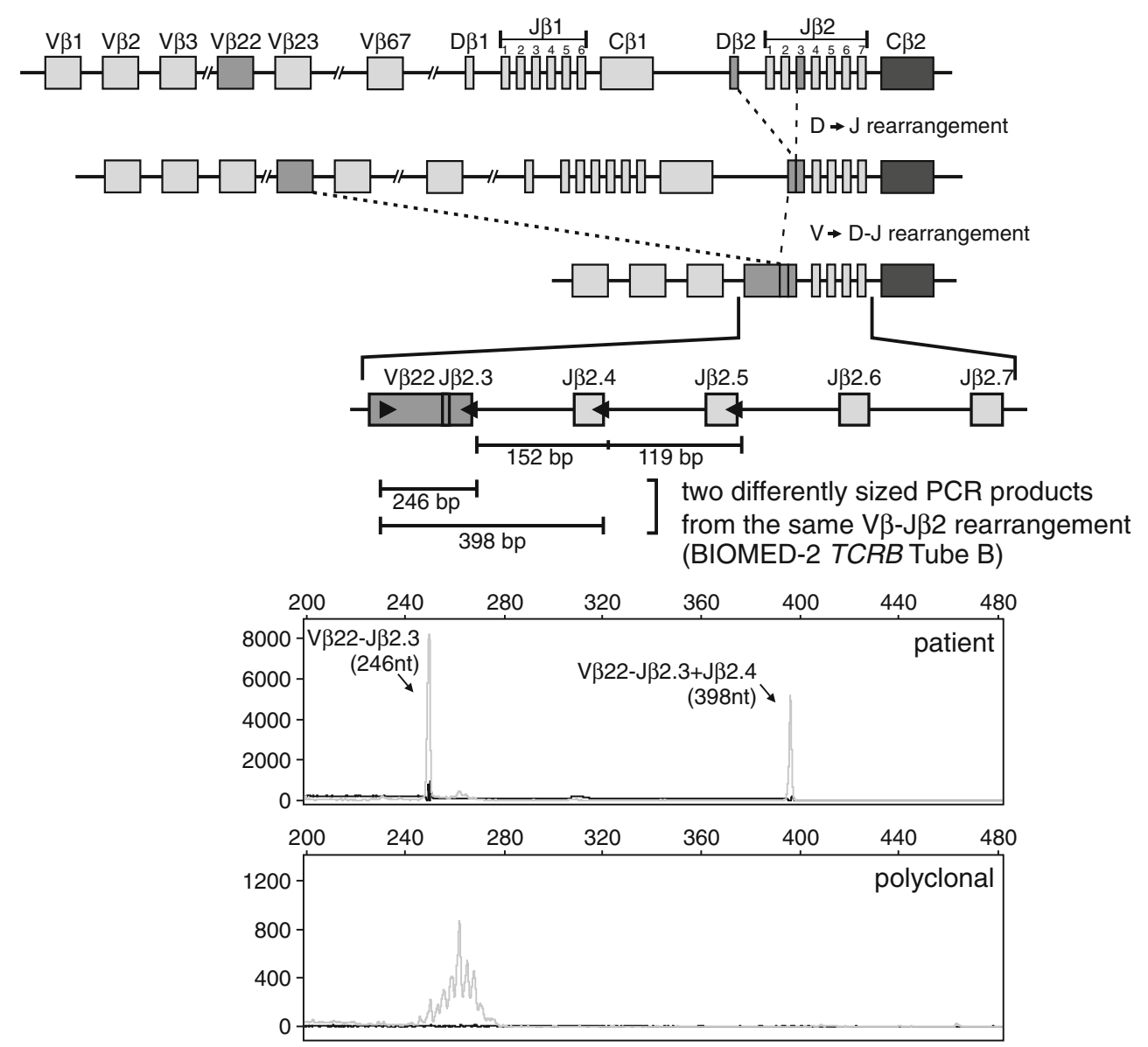

stream $\mathrm{J} \beta$ segment is recognized by the corresponding primer in the second mixture.

A complex interpretation pitfall concerns the question whether detection of multiple clonal signals is equivalent to biclonality. Although biclonal malignancies do occur, first, several immunobiological and technical explanations for multiple clonal signals should be considered. Since lymphocytes carry two chromosomes, biallelic rearrangements are more common than biclonality. Second, J segment clusters such as in the TCRB locus (but also in the IGH, $I G K$ loci) might give rise to additional "clonal" signals caused by differently sized PCR products derived from the same rearrangement. Third, the TCRB locus has a more complex configuration in that two rearrangements can occur simultaneously on the same allele, mounting up to a total of four rearrangements per T-cell clone: a $V-J \beta 1$ or $D \beta 1-J \beta 1$ rearrangement can be followed by a $D \beta 2-J \beta 2$ rearrangement on the very same allele [28]. Taken together, all these phenomena illustrate that, in the case of multiple clonal signals, biclonality is more of an exception to the rule.

Clonality interpretation should also be performed in the context of immunobiology. A well-known pitfall concerns the detection of oligoclonality or even (low level) monoclonality of $\mathrm{T}$ lymphocytes under certain immunobiologic conditions [29-35]. Detection of an oligoclonal T-cell repertoire in elderly individuals should be considered as a potential sign of an involuting immune system due to aging of the system (immunosenescence) [36]. Repeated analysis using the same sample, a second independent DNA extraction form the same sample and/or a related sample need to be evaluated for consistency of the results. In true reactive lesions, oligoclonality or even monoclonality may reflect an exaggerated immune response with a dominant immunospecificity. Apart from repeated molecular analysis, a careful combined (re)evaluation of the clinical, histopathologic, and molecular findings is needed to correctly interpret oligo-/monoclonality results.

\section{Interactive interpretation model}

Knowledge about technical and immunobiological pitfalls of TCR rearrangement analysis is of utmost importance, but it does not suffice in all cases. For appropriate interpretation of the molecular data, it is essential to combine these data with data from immunohistology and preferably also with the results from flow cytometric immunophenotyping. Such an interactive interpretation model, with regular contacts between clinical molecular biologists, pathologists, hematologists, and immunologists guarantees integration of all 
available data to reach the most reliable diagnosis. Especially, the percentage of suspect malignant lymphocytes and the percentages of normal (reactive) B and $\mathrm{T}$ lymphocytes, as available from histopathology and/or flow cytometry, are important parameters to be considered for estimating the relevance of the TCR clonality findings. Thus, the finding of weak clonal signals (in one or more targets) in a background of polyclonal signals is hardly compatible with a large suspect cell population, and hence, such TCR findings should be interpreted with caution. On the other hand, absence of both monoclonal and polyclonal $T C R G$ patterns in a sample showing a large T-cell infiltrate is not compatible and should lead to further analysis of other TCR targets before definitive conclusions can be drawn. Finally, the interpretation of clonality can also be dependent on the clinical presentation. Regular discussions of cases in multidisciplinary patient meetings should avoid the aforementioned misinterpretations.

Acknowledgements This review is based on the results and discussions with many colleagues all over Europe in the BIOMED-2 Concerted Action "PCR-based clonality detection in suspect lymphoproliferations" (BMH4-CT98-3936). We thank Margarethe van Altena, Annemiek van Raaij, Paul Rombout (Radboud University Nijmegen Medical Centre, Nijmegen), and Ingrid LM WolversTettero, Ellen J van Gastel-Mol, Monique ECM Oud, Brenda Verhaaf (Erasmus MC, Rotterdam) for technical assistance.

Open Access This article is distributed under the terms of the Creative Commons Attribution Noncommercial License which permits any noncommercial use, distribution, and reproduction in any medium, provided the original author(s) and source are credited.

\section{References}

1. Van Dongen JJM, Wolvers-Tettero ILM (1991) Analysis of immunoglobulin and $\mathrm{T}$ cell receptor genes. Part I: Basic and technical aspects. Clin Chim Acta 198:1-92

2. Van Dongen JJM, Wolvers-Tettero ILM (1991) Analysis of immunoglobulin and T cell receptor genes. Part II: Possibilities and limitations in the diagnosis and management of lymphoproliferative diseases and related disorders. Clin Chim Acta 198:93-174

3. Tonegawa S (1983) Somatic generation of antibody diversity. Nature 302:575-581

4. Davis MM, Bjorkmann PJ (1988) T-cell antigen receptor genes and T-cell recognition. Nature 334:395-402

5. Van Zelm MC, Van Der Burg M, De Ridder D et al (2005) Ig gene rearrangement steps are initiated in early human precursor B cell subsets and correlate with specific transcription factor expression. J Immunol 175:5912-5922

6. Dik WA, Pike-Overzet K, Weerkamp F et al (2005) New insights on human $\mathrm{T}$ cell development by quantitative $\mathrm{T}$ cell receptor gene rearrangement studies and gene expression profiling. J Exp Med 201:1715-1723

7. Quertermous T, Strauss WM, Van Dongen JJ, Seidman JG (1987) Human $\mathrm{T}$ cell gamma chain joining regions and $\mathrm{T}$ cell development. J Immunol 138:2687-2690
8. Lefranc MP (2003) IMGT, the international ImMunoGeneTics database. Nucleic Acids Res 31:307-310

9. Lefranc MP (2003) IMGT databases, web resources and tools for immunoglobulin and $\mathrm{T}$ cell receptor sequence analysis, http:// imgt.cines.fr. Leukemia 17:260-266

10. Bottaro M, Berti E, Biondi A, Migone N, Crosti L (1994) Heteroduplex analysis of T-cell receptor gamma gene rearrangements for diagnosis and monitoring of cutaneous T-cell lymphomas. Blood 83:3271-3278

11. Langerak AW, Szczepanski T, Van Der Burg M, Wolvers-Tettero IL, Van Dongen JJ (1997) Heteroduplex PCR analysis of rearranged $\mathrm{T}$ cell receptor genes for clonality assessment in suspect T cell proliferations. Leukemia 11:2192-2199

12. Kneba M, Bolz I, Linke B, Bertram J, Rothaupt D, Hiddemann W (1994) Characterization of clone-specific rearrangement T-cell receptor gamma-chain genes in lymphomas and leukemias by the polymerase chain reaction and DNA sequencing. Blood 84:574-581

13. Kneba M, Bolz I, Linke B, Hiddemann W (1995) Analysis of rearranged T-cell receptor beta-chain genes by polymerase chain reaction (PCR) DNA sequencing and automated high resolution PCR fragment analysis. Blood 86:3930-3937

14. Van Dongen JJM, Langerak AW, Bruggemann M, Evans PA, Hummel M, Lavender L et al (2003) Design and standardization of PCR primers and protocols for detection of clonal immunoglobulin and T-cell receptor gene rearrangements in suspect lymphoproliferations. Report of the BIOMED-2 Concerted Action BMH4-CT98-3936. Leukemia 17:2257-2317, This paper is an extensive technological review article on the standardization of the multiplex PCR strategy of the BIOMED-2 consortium

15. Van Krieken JHJM, Langerak AW, Macintyre EA, Kneba M, Smith JL, Garcia-Sanz R et al (2007) Improved reliability of lymphoma diagnostics via PCR-based clonality testing. Report of the BIOMED-2 Concerted Action BHM4-CT98-3936. Leukemia 21:201-206, This paper gives a summary of the clinical diagnostic studies as performed by the BIOMED-2 consortium and provides an algorithm to use the multiplex PCR strategy in routine practice; see also references 33-35

16. Evans PAS, Pott CH, Groenen PJTA, Salles G, Davi F, Berger F et al (2007) Significantly improved PCR-based clonality testing in B-cell malignancies by use of multiple immunoglobulin gene targets: Report of the BIOMED-2 Concerted Action BHM4CT98-3936. Leukemia 21:207-214

17. Bruggemann M, White H, Gaulard P, Garcia-Sanz R, Gameiro P, Oeschger S et al (2007) Powerful strategy for PCR-based clonality assessment in T-cell malignancies. Report of the BIOMED-2 Concerted Action BHM4-CT98-3936. Leukemia 21:215-221

18. Langerak AW, Molina TJ, Lavender FL, Pearson D, Flohr T, Sambade C et al (2007) PCR-based clonality testing in tissue samples with reactive lymphoproliferations: usefulness and pitfalls. A study from the BIOMED-2 Concerted Action BMH4CT98-3936. Leukemia 21:222-229

19. Sandberg Y, Heule F, Lam KH, Lugtenburg PJ, WolversTettero ILM, Van Dongen JJM et al (2003) Molecular Ig/TCR clonality analysis in cutaneous lymphoproliferations. Experience with the BIOMED-2 standardized polymerase chain reaction protocol. Haematologica 88:659-670

20. Sandberg Y, Van Gastel-Mol EJ, Verhaaf B, Lam KH, Van Dongen JJM, Langerak AW (2005) BIOMED-2 multiplex Ig/TCR PCR protocols can reliably replace Southern blot analysis in routine clonality diagnostics. J Mol Diagn 7:495-503

21. Matthews C, Catherwood M, Morris TC, Alexander HD (2004) Routine analysis of IgVH mutational status in CLL patients using BIOMED-2 standardized primers and protocols. Leuk Lymphoma 45:1899-1904

22. Lassmann S, Gerlach UV, Technau-Ihling K, Werner M, Fisch P (2005) Application of BIOMED-2 primers in fixed and decalcified 
bone marrow biopsies: analysis of immunoglobulin $\mathrm{H}$ receptor rearrangements in B-cell non-Hodgkin's lymphomas. J Mol Diagn 7:582-591

23. McClure RF, Kaur P, Pagel E, Quillette PD, Hotegaard CE, Treptow CL et al (2006) Validation of immunoglobulin gene rearrangement detection by PCR using commercially available BIOMED-2 primers. Leukemia 20:176-179

24. Halldorsdottir AM, Zehnbauer BA, Burack WR (2007) Application of BIOMED-2 clonality assays to formalin-fixed paraffin embedded follicular lymphoma specimens: superior performance of the IGK assays compared to IGH for suboptimal specimens. Leuk Lymphoma 48:1338-1343

25. Langerak AW, Groenen PJTA, Van Krieken JHJM, Van Dongen JJM (2007) Immunoglobulin/T-cell receptor clonality diagnostics. Expert Opin Med Diagn 1(4):451-461

26. Sandberg Y, Verhaaf B, Van Gastel-Mol EJ, Wolvers-Tettero ILM, De Vos AW, McLeod RAF et al (2007) Human T-cell lines as controls for detection of T-cell receptor gene rearrangements via the multiplex BIOMED-2 PCR tubes. Leukemia 21:230-237

27. Langerak AW (2008) Undersized, oversized? It is not one-size-fitsall in lymphoid clonality detection. Leukemia Res 32(2):203-204

28. Langerak AW, Wolvers-Tettero ILM, Van Dongen JJM (1999) Detection of $\mathrm{T}$ cell receptor beta (TCRB) gene rearrangement patterns in $\mathrm{T}$ cell malignancies by Southern blot analysis. Leukemia 13:965-974

29. Malik UR, Oleksowicz L, Dutcher JP, Ratech H, Borowitz MJ, Wiernik PH (1996) Atypical clonal T-cell proliferation in infectious mononucleosis. Med Oncol 13:207-213
30. Katchar K, Wahlstrom J, Eklund A, Grunewald J (2001) Highly activated T-cell receptor AV2S3(+) CD4(+) lung T-cell expansions in pulmonary sarcoidosis. Am J Respir Crit Care Med 163:1540-1545

31. Van Leeuwen EM, Remmerswaal EB, Vossen MT, Rowshani AT, Wertheim-Van Dillen PM, Van Lier RA et al (2004) Emergence of a CD4+CD28- granzyme $\mathrm{B}+$, cytomegalovirus-specific $\mathrm{T}$ cell subset after recovery of primary cytomegalovirus infection. J Immunol 173:1834-1841

32. Gamadia LE, Van Leeuwen EM, Remmerswaal EB, Yong SL, Surachno S, Wertheim-Van Dillen PM et al (2004) The size and phenotype of virus-specific $\mathrm{T}$ cell populations is determined by repetitive antigenic stimulation and environmental cytokines. J Immunol 172:6107-6114

33. Posnett DN, Sinha R, Kabak S, Russo C (1994) Clonal populations of $\mathrm{T}$ cells in normal elderly humans: the $\mathrm{T}$ cell equivalent to "benign monoclonal gammapathy". J Exp Med 179:609-618

34. Iijima T, Inadome $Y$, Noguchi M (2000) Clonal proliferation of B lymphocytes in the germinal centers of human reactive lymph nodes: possibility of overdiagnosis of B cell clonal proliferation. Diagn Mol Pathol 9:132-136

35. Brauninger A, Yang W, Wacker HH, Rajewsky K, Kuppers R, Hansmann ML (2001) B-cell development in progressively transformed germinal centers: similarities and differences compared with classical germinal centers and lymphocyte-predominant Hodgkin disease. Blood 97:714-719

36. Vargas RL, Felgar RE, Rothberg PG (2008) Detection of clonality in lymphoproliferations using PCR of antigen receptor genes: does size matter ? Leukemia Res 32(2):335-338 